\title{
Zs Research Square \\ A description of self-medication with cannabis among adults with legal access to cannabis
}

\author{
Antoine Asselin \\ Université Laval: Universite Laval \\ Olivier Beauparlant Lamarre \\ Université Laval: Universite Laval \\ Richard Chamberland \\ Université Laval: Universite Laval

\section{Sarah-Jeanne Mc Neil} \\ Université Laval: Universite Laval \\ Éric Demers \\ CHU de Québec-Université Laval: CHU de Quebec-Universite Laval \\ Arsene Zongo ( $\square$ arsene.zongo@pha.ulaval.ca ) \\ Université Laval: Universite Laval https://orcid.org/0000-0001-8812-3088
}

\section{Research Article}

Keywords: survey, cannabis, self-medication, use patterns

Posted Date: June 22nd, 2021

DOI: https://doi.org/10.21203/rs.3.rs-528768/v1

License: (c) (i) This work is licensed under a Creative Commons Attribution 4.0 International License. Read Full License 


\section{Abstract \\ Objective}

Little is known about self-medication with cannabis post-recreational cannabis legalization in Canada. We aimed to establish a detailed portrait of self-medication with cannabis among adults in Quebec.

\section{Methods}

We conducted an online survey from November 2020 to January 2021 among individuals aged $\geq 21$ years, who endorsed using cannabis bought in legal recreational cannabis stores to self-medicate a health condition. Data were analysed using descriptive statistics and stratified according to sex, age and the type of cannabis use (exclusively medical versus medical and recreational use).

\section{Results}

489 participants were included. Median age was 34 years, and $48 \%$ were women. About $25 \%$ reported an exclusive medical use of cannabis. Treated conditions included anxiety (70\%), insomnia (56\%), pain (53\%), depression (37\%), and many other. Reasons for not consulting in cannabis clinics included lack of information (52\%), complexity of the process (39\%), accessibility of cannabis clinics $(23 \%)$ and other.

\section{Introduction}

The use of cannabis for medical purposes has been legal in Canada since 2001 (1). Access to cannabis through the medical circuit was a complex process conditioned by a medical prescription, an authorization granted by Health Canada (i.e., the Canadian health regulatory agency), and finally the registration to a Health Canada licenced cannabis producer/seller where the registered patient should purchase his/her cannabis (1). Patients can also opt to self-grow their cannabis for their medical need following Health Canada authorization (1). These constraining conditions had certainly promoted self-medication with cannabis through the illegal market during the period where cannabis was illegal in Canada. The process was somewhat relaxed in 2018 by allowing patients with a medical cannabis prescription to directly register and purchase their cannabis with a licensed seller and thus skipping the formal authorization by Health Canada (1). In October 2018, Canada legalised the production, sale, and consumption of cannabis for recreational purposes (2). Since the provinces are responsible for enforcing the law, Quebec decided to supervise the trade through a public society, i.e., the Société québécoise du cannabis (SQDC) $(3,4)$. This not-for-profit society has the monopoly for recreational cannabis sale within the province and does not promote the consumption of cannabis $(3,4)$.

The legalisation of cannabis for recreational use has facilitated the access of cannabis for both recreational and medical use (5, 6). The 2019 Quebec provincial cannabis survey showed that cannabis was used to treat a health condition by $23.5 \%$ of cannabis users as reported by the study participants (6). However, only $4.6 \%$ of participants reported acquiring their cannabis from producers licenced by Health Canada, suggesting that the majority of those who reported medical use were acquiring their cannabis from the recreational market, relatives, or illegal sellers. A 2019 Canadian survey of medical cannabis users also showed that $45 \%$ of participants never had a medical document for their cannabis (7). The main sources of acquisition were licenced producers (38\%), informal (37\%) and legal recreational cannabis stores (47\%) (7). A study carried out by Sexton et al. in the United States found that $60 \%$ of respondents who reported a medical use of cannabis used cannabis without a medical advice (8).

Self-medication with cannabis could present some risks for users. Main concerns include possible intoxication for nonstandardized or high cannabis dosage (9), users experiencing known and unknown adverse events (9) including cannabis-drug 
interaction for those with prescribed medications (10). This is particularly critical considering the lack of minimal benefit-risk assessment prior to cannabis use for those individuals. For all these reasons, a description of the phenomenon that would help to understand the problem and implement solutions is needed. However, although surveys have documented cannabis use by distinct patient groups, very few have specifically targeted individuals using cannabis for self-medication, particularly postrecreational cannabis legalization in Canada. Considering the increasing popularity of therapeutic cannabis use and the potential risks associated with its use, the present study was designed to examine the global portrait of self-medication with cannabis in the province of Quebec including users' characteristics, reasons for self-medication, conditions treated, patterns of cannabis and other drugs use, and healthcare and other resources utilization.

\section{Methods}

\section{Study design}

This is a cross-sectional study conducted through an online survey that took place between November $10^{\text {th }}, 2020$ and January $31^{\text {th }}, 2021$.

\section{Study population}

All individuals aged 21 years or older (i.e., legal age to access cannabis in Quebec) were eligible to complete the survey if they spoke French and reported self-medication with cannabis acquired at the SQDC. We defined self-medication with cannabis as the use of cannabis-based product for the prevention, treatment or alleviation of symptoms of a physical or psychological illness.

\section{Data collection}

Data were collected through LimeSurvey, a web-based platform. The study questionnaire was developed by the research team and comprised 48 questions grouped in six sections. Section 1 was about the source of cannabis supply and the reasons for consumption (recreational or medical), the objective being to exclude participants who used exclusively cannabis for recreational purposes. Section 2 was composed of questions about demographic characteristics (age, gender, income, administrative region of the participant, etc.). Section 3 focused on conditions treated and pattern of cannabis use (conditions treated, variety of cannabis, tetrahydrocannabinol (THC) and cannabidiol (CBD) dosages, frequency of consumption, route of administration, and use of other drugs). Section 4 assessed the perceived effects of cannabis (not reported in this manuscript). Section 5 inquired about barriers to access the medical cannabis circuit. The last section assessed the perceived role of healthcare professionals. The questionnaire was first pre-tested with few selected participants and modifications were provided.

Three questions were added after the launch of the survey and were thus completed by a subset of the participants. These questions assessed 1) the declaration of cannabis use to healthcare professionals, 2) willing to have easier access to advice from healthcare professionals related to their medical use of cannabis and 3) the impact of COVID-9 pandemic on cannabis consumption for participants who were using cannabis before the pandemic.

The recruitment was promoted through social medias (mainly Facebook), patients' associations such as Quebec Association for Chronic Pain, and leaflets distributed in pharmacies. An online consent form had to be read and agreed by all participants before accessing the study questionnaire.

\section{Statistical analysis}


The analyses were mainly descriptive and consisted of calculating proportions for categorical variables and mean and median for continuous variables. First, we analysed the characteristics of the participants that we stratified by gender and the type of cannabis use (exclusively medical or mixed medical and recreational use). Next, we described the conditions treated with cannabis, the reasons for self-medication, the patterns of cannabis use, and other medications used concurrently. To further describe the portrait of cannabis use for self-medication, we also stratified the analysis by some characteristics such as age, gender to highlight differences or similarities that may exist between certain groups. For stratification by gender (women, men, and other gender), we could only consider men and women categories as the third category represented few participants. For the comparisons, chi-square test (for categorical variables) and Student t-test (for continuous variables) were conducted. P-values below 0.05 were considered statistically significant. The data were analyzed with SAS version 9.4 (SAS Institute, Cary, NC, USA).

\section{Results}

\section{Participant's characteristics}

Out of 1451 participants who interacted with the survey, a total of 660 participants completed the questionnaire. From this group, 489 were included for analysis after the exclusion of 1 participant who was under 21 years old, 98 subjects who reported recreational cannabis use only, and 72 subjects who did not use cannabis products bought at SQDC (from illegal sources or licensed producers). The mean age of the 489 participants was 36 years (age range: $21-77$ years), $48,67 \%$ were women, $48.06 \%$ men, and $3.27 \%$ reported other gender (Table 1$)$. About $25 \%(n=122)$ reported using cannabis only for medical purposes while the other $75 \%$ declared using cannabis for both recreational and medical purposes. Almost half of respondents who use cannabis for both purposes were under 30 years (47.54\%) while this proportion was $26,23 \%$ among the exclusive medical users. Women reported exclusive medical use more frequently compared to men (59.84 \% vs $37.70 \%)$. Participants were distributed in all the regions of Quebec. The quasi-totality of respondents were Caucasians (93.57\%).

\section{Reasons for self-medication with cannabis}

The main reasons reported for not consulting cannabis clinics were the lack of information on the medical access of cannabis (52.85\%), the perceived complexity of the process (39.86\%), the difficulty accessing a cannabis clinic (23.23\%), the inconvenience of the follow-up with a physician for cannabis $(20.27 \%)$, the inability to choose the cannabis products $(18.91 \%)$, the delay to obtain cannabis in the medical circuit $(16,17 \%)$ and the price $(12,07 \%)$ (Table 2$)$. In general, men and participants under 34 years were more likely to report a reason limiting their access to a cannabis clinic (Table 2).

\section{Treated health conditions}

The number of treated conditions per participant varied from 1 to 13 . Only $13 \%$ reported using cannabis to treat a single health condition or symptom. About two thirds (65.64\%) of respondents were using cannabis for 2 to 5 concomitant conditions or symptoms while $20.99 \%$ treated 6 or more simultaneously. Cannabis was more frequently used to treat psychological conditions than physical conditions (85.57\% vs $74.43 \%)$. Anxiety (70.93\%), insomnia (56.49\%), depression (37.94\%) and attention deficit hyperactivity disorder (ADHD) (25.57\%) were the most frequently reported psychological conditions. Chronic non-cancer pain (53.40\%), headache/migraine (28.45\%), muscle spasticity (16,70\%) and bowel disease (11.34\%) were the most reported physical conditions. While men mostly treat ADHD, shyness or depression, women more frequently treat anxiety, nausea, headaches or bowel disease (Table 3). However, use of cannabis for chronic pain was similar between men and women $(54.08 \%$ vs. $53.16 \%, p$ $=0.84$ ).

Conditions treated also slightly varied by age as presented in Table 3. Participants under 34 years treat psychological conditions more than older patients $(90.04 \%$ vs $80.77 \%, p=0.004)$ (Table 3$)$.

\section{Patterns of cannabis use}

Page $4 / 21$ 
Table 4 displays reported patterns of cannabis use, with stratification for the type of use (exclusively medical or mixed). Regarding THC and CBD ratio, 35\% used products with higher THC than CBD and 13\% used products with only THC. Regarding potency, about two thirds reported they mostly used products with THC concentration $>10 \%$ while $45 \%$ used product with CBD concentration $>10 \%$. Differences were notable according to the type of cannabis use. Namely, exclusive medical users were more likely to use products stronger in CBD than THC (27.50\% vs $17.70 \%)$, or products containing only CBD $(22.50 \%$ vs $8.99 \%)$.

Regarding modes of use, more than one mode of use was reported by some participants. Smoking was reported by the majority of participants (81.19\%) followed by ingestion (48.26\%) (Table 4). Smoking was less preferred by exclusive medical users compared to mixed users (Table 4).

For frequency of use, $45.71 \%$ of respondents reported daily cannabis use while $32.53 \%$ reported weekly to near-daily use.

The majority of participants reported treating a health conditions with cannabis for $\geq 1$ year.

\section{Concurrent use of other medications}

A total of 276 (56.44\%) participants reported having other prescribed drugs. Among them, 223 reported using their prescribed drugs while 53 mentioned not using their drugs. Drugs' names were provided by 247 participants. The most mentioned drugs were for pain and for psychiatric disorders (Table 5).

\section{Healthcare resources and other resources utilization}

About $46 \%$ of study participants reported that all their treated conditions were diagnosed by a physician, with a higher representation of exclusive medical cannabis users in this category (60.83\% versus $41.16 \%$ for mixed users) (Table 6).

For information on cannabis, participants reported having consulted SQDC retailers (36.81\%), physicians (29.24\%), illegal sellers $(9.20 \%)$ and pharmacists $(7.36 \%)$. However, $39 \%$ of all participants reported that they had never consulted a resource about their self-medication with cannabis (Table 6).

Specifically focusing on the 36 participants who reported having consulted a pharmacist, the main reason was to ask for the safety to combine cannabis with other medications (29/36). 19/36 reported being satisfied with the pharmacist advice (Supplemental Table 1).

The three questions added after the launch of the survey were completed by 351 participants. About $15 \%$ of them reported that they never declared their self-medication with cannabis to healthcare professionals (Table 6). Exclusive medical users were more likely to never report their cannabis use to healthcare professionals compared to medical and recreational users (21\% vs $13 \%)$.

The proportion of women who reported that they never declared their cannabis use was similar to men (17\% vs $12 \%)$.

Interestingly, $80.47 \%$ of all respondents answered that they were willing to have easier access to health professionals for advice related to their medical use of cannabis.

\section{Impact of COVID-19 on cannabis consumption}

From the 357 participants who completed the three questions added after the launch of the survey, 18 indicated that the question on the pandemic effect was not applicable to them (Please note that the question was addressed to participants who were self-medicating with cannabis before the pandemic). From the remaining 339 participants, 139 (41.00\%), 185 (54.57\%) and 15 (4.43\%) reported an increase, no change, and a decrease in their use of cannabis, respectively.

\section{Discussion}

This study showed that individuals who self-medicate with cannabis are younger, in similar proportion of men and women, and use cannabis to treat a wide range of conditions. Reasons for self-medication include lack of information as well as administrative and medical issues. Patterns of use were highly variable and more than half reported the use of other 
medications. Finally, not all self-medicated cannabis systematically report their cannabis use to healthcare providers. Collectively, these descriptive data provide a complete picture of self-medication with cannabis that is essential to understand the problem and start conceiving strategies or policies to solve it. To our knowledge, this is the first study that formally described self-medication with cannabis in the general population post-recreational cannabis legalization in Canada.

The observation that individuals who self-medicate with cannabis are mainly young is consistent with the portrait of cannabis use in the general population $(5,6)$ and suggests that the 2018 recreational cannabis legalization does not result in a significant shifting of cannabis use toward older persons. Our recruitment methods (online survey with focus on social medias) may in part explain this higher representativity of younger individuals in our sample. Moreover, age distribution among exclusive medical users and mixed medical and recreational users was similar to results observed in a survey conducted before the legalization of cannabis in Canada showing that exclusive medical cannabis users tended to be older than mixed users (11). In our survey, the observed similar proportion of men and women is not consistent with previous surveys of cannabis users $(11,12)$. For example, Turna et al. observed a higher proportion of women (59\%) among cannabis users (exclusive medical and mixed users) who were surveyed before cannabis legalization (11) while Lucas et al observed a high proportion of men (73\%) in their survey conducted in 2015 among patients registered with a licensed cannabis producer (12). Our method of recruitment (advertisement in social media with emphasis towards women), and the fact that some of the groups who shared our survey were associations for women's health and cannabis, may explain our similar proportion of men and women. The observation that women in our sample more often reported an exclusive medical use of cannabis than men was also observed by Turna et al. (11). As opposed to age, where individuals were mainly younger, it is interesting to note that individuals with low, medium and high income were all relaying on cannabis to self-medicate their pathology $(44 \%$ had $>50,000 \$)$. This observation is consistent with previous studies $(11,12)$.

Main conditions treated by participants in our sample are similar to those reported in previous survey of patients seeking cannabis to treat a health condition $(8,11,12)$. These treated conditions were consistent with the potential pharmacologic effects of cannabis and cannabinoids in the literature $(13,14)$. The high number of conditions treated per participant is problematic and suggest that cannabis may be perceived as effective for a wide range of conditions, which is not supported by current literature. More communication is needed to inform patients on the lack of scientific evidence on the efficacy of cannabis for most of claimed indications, potential risks, and potential interactions with other drugs.

Regarding patterns of use, the observation that THC concentration $>20 \%$ was reported by a high proportion of participants (i.e., $32 \%)$ is a concern as it may exposed users to acute toxic effects as well as to long-term adverse effects of cannabis (15). This is particularly a concern as a majority of participants reported using cannabis for one year or more to treat a health condition (74\%). The lack of medical assistance may explain this use of high concentrations of THC and CBD.

Consistent with the fact that CBD is usually presented as having therapeutic benefits but has less or no psychoactive effects as compared to THC $(15,16)$, we observed that exclusive medical users had preference for CBD dominant products. This preference for $\mathrm{CBD}$ dominant products is in accordance with previous literature $(8,11)$. However, consumption of high doses of CBD $(>20 \%)$ was also a concern as it may expose individuals to potentials risk.

As compared to previous studies of medical cannabis users $(8,11,12)$, smoking was the preferred consumption method in our sample. This chronic smoking of cannabis (a majority of participants reported using cannabis for more than one year) could potentially negatively impact the respiratory health of users in the long-term (17).

The barriers to accessing medical cannabis are consistent with those reported in previous studies $(12,18,19)$. However, the main reason in these studies was usually the cost $(12,18,19)$, while the lack of information and complexity of the process were more prevalent in our sample. The fact that our sample specifically targeted self-medicated individuals may explain this difference. Interestingly, the high majority of participants (80\%) reported that they would be interested to have counseling and advice from a healthcare professional for their cannabis use. This information suggests that policies and interventions implemented to target those patients for a safer use of cannabis within the healthcare system would be successful. More specifically, addressing the reported barriers to accessing cannabis through the medical circuit is warranted. Particularly, adding medical cannabis services in ambulatory care, decomplexifying the process to obtain medical cannabis and communication 
could help to reduce self-medication with cannabis and ensure patients' safety. Developing and strengthening the cannabisrelated expertise of healthcare professionals is also needed for them to engage appropriate and reassuring discussions with their patients on cannabis, rather than strict refusal or stigmatization, as reported by some participants in our survey and in previous surveys $(12,18)$. This is particularly important to avoid conveying patients towards recreational cannabis sellers or illegal sellers to seek for advice to use cannabis for their medical conditions as observed in this survey.

\section{Limitations}

First, our study sample may not be representative of the population of individuals using cannabis for self-medication as we mainly recruit individuals who have access to internet with a higher representation of those using social media or members of specific patients' associations. There is also a lack of ethnic diversity. However, a random sample was not possible to draw, as the target population was not clearly identifiable. Recall and memory biases could also have potentially affected the results. Social desirability bias could also be a concern for certain questions. However, the use of an anonymized online survey reduced this possibility. Finally, information bias due to the missing data could be a concern. However, the proportion of individuals with missing data per variable was small in general, thus minimizing this issue.

\section{Conclusion}

Despite the lack of clear and strong evidence supporting the health benefits of cannabis, our study shows that cannabis is used to treat a wide range of conditions without a medical prescription or supervision. Use of higher doses of THC and CBD and smoking as preferred method of use may pose certain risks to individuals. Concerns also exist with the fact that many users do not systematically declare their use to healthcare professionals which may cause additional risk due to possible interaction between cannabis and other prescribed medications. Addressing the reported barriers to cannabis access through the medical circuit is urgently needed.

\section{References}

1. Health Canada. Cannabis for medical purposes under the Cannabis Act: information and improvements (Available from: https://www.canada.ca/en/health-canada/services/drugs-medication/cannabis/medical-usecannabis.html\#_Access_to_cannabis last access: 2021-05-3). 2020.

2. Justice Canada. Cannabis Legalization and Regulation (available from: https://www.justice.gc.ca/eng/cj-jp/cannabis/ last access: 2021-05-06).

3. Gouvernement du Québec. Loi encadrant le cannabis (available from: https://encadrementcannabis.gouv.qc.ca/loi/loiencadrant-le-cannabis/ last access: 2021-05-07).

4. Société Québécoise Du Cannabis (available from: https://www.sqdc.ca/en-CA/).

5. Statistiques Canada. Enquête canadienne sur le cannabis de 2020 : Sommaire (available from: https://www.canada.ca/fr/sante-canada/services/drogues-medicaments/cannabis/recherches-donnees/enquetecanadienne-cannabis-2020-sommaire.html last access: 2021-05-06). 2020.

6. Roy V, Conus F. Enquête québécoise sur le cannabis 2019. Méthodologie de l'enquête et caractéristiques de la population visée, [En ligne], Québec, Institut de la statistique du Québec, 35 p. (Available from: https://statistique.quebec.ca/en/fichier/enquete-quebecoise-sur-le-cannabis-2019-methodologie-de-lenquete-etcaracteristiques-de-la-population-visee.pdf last access: 2021-05-07). 2020.

7. Canada Pharmacists Association (CPhA). CPhA medical cannabis study medical 2019 (Available from: https://www.pharmacists.ca/cpha-ca/assets/File/cpha-on-the-issues/Cannabis\%20Survey_Patients-GenPub.pdf last access: 2021-05-07). 
8. Sexton M, Cuttler C, Finnell JS, Mischley LK. A Cross-Sectional Survey of Medical Cannabis Users: Patterns of Use and Perceived Efficacy. Cannabis Cannabinoid Res. 2016;1(1):131-8.

9. Volkow ND, Baler RD, Compton WM, Weiss SR. Adverse health effects of marijuana use. N Engl J Med. 2014;370(23):2219-27.

10. Vazquez M, Guevara N, Maldonado C, Guido PC, Schaiquevich P. Potential Pharmacokinetic Drug-Drug Interactions between Cannabinoids and Drugs Used for Chronic Pain. Biomed Res Int. 2020;2020:3902740.

11. Turna J, Balodis I, Munn C, Van Ameringen M, Busse J, MacKillop J. Overlapping patterns of recreational and medical cannabis use in a large community sample of cannabis users. Compr Psychiatry. 2020;102:152188.

12. Lucas P, Walsh Z. Medical cannabis access, use, and substitution for prescription opioids and other substances: A survey of authorized medical cannabis patients. Int J Drug Policy. 2017;42:30-5.

13. Whiting PF, Wolff RF, Deshpande S, Di Nisio M, Duffy S, Hernandez AV, et al. Cannabinoids for Medical Use: A Systematic Review and Meta-analysis. JAMA. 2015;313(24):2456-73.

14. Montero-Oleas N, Arevalo-Rodriguez I, Nunez-Gonzalez S, Viteri-Garcia A, Simancas-Racines D. Therapeutic use of cannabis and cannabinoids: an evidence mapping and appraisal of systematic reviews. BMC Complement Med Ther. 2020;20(1):12.

15. Health Canada. Cannabis in Canada: Get the facts (availaible

from: https://www.canada.ca/en/services/health/campaigns/cannabis/health-effects.html last access: 2021-05-07).

16. MacCallum CA, Russo EB. Practical considerations in medical cannabis administration and dosing. Eur J Intern Med. 2018;49:12-9.

17. Gates P, Jaffe A, Copeland J. Cannabis smoking and respiratory health: consideration of the literature. Respirology. 2014;19(5):655-62.

18. Valencia $\mathrm{Cl}$, Asaolu IO, Ehiri JE, Rosales C. Structural barriers in access to medical marijuana in the USA-a systematic review protocol. Syst Rev. 2017;6(1):154.

19. Sznitman SR, Lewis N. Examining effects of medical cannabis narratives on beliefs, attitudes, and intentions related to recreational cannabis: A web-based randomized experiment. Drug Alcohol Depend. 2018;185:219-25.

\section{Tables}

Table 1: Characteristics of participants who reported a self-medication with cannabis 


\begin{tabular}{|c|c|c|c|c|c|}
\hline \multirow[t]{2}{*}{ Characterstics* } & \multicolumn{2}{|l|}{ Gender\$ } & \multicolumn{3}{|c|}{ Type of cannabis use } \\
\hline & $\begin{array}{l}\text { Men } \\
(n=235)\end{array}$ & $\begin{array}{l}\text { Women } \\
(n=238)\end{array}$ & $\begin{array}{l}\text { Medical use } \\
\text { only } \\
(n=122)\end{array}$ & $\begin{array}{l}\text { Medical + } \\
\text { recreationnal use } \\
(n=367)\end{array}$ & $\begin{array}{l}\text { Total } \\
\text { participants } \\
\left(\begin{array}{l}n=489) \mathrm{N} \\
(\%)\end{array}\right.\end{array}$ \\
\hline \multicolumn{6}{|l|}{ Gender } \\
\hline Male & - & - & 46 (37.70) & $189(51.50)$ & $235(48.06)$ \\
\hline Female & - & - & $73(59.84)$ & $165(44.96)$ & $238(48.67)$ \\
\hline Other & - & - & $3(2.46)$ & $13(3.54)$ & $16(3.27)$ \\
\hline \multicolumn{6}{|l|}{$\begin{array}{l}\text { Age }(\text { mean }=36 \text { years, } \min =21, \max =77, \\
\text { median }=34)\end{array}$} \\
\hline $21-30$ & $\begin{array}{l}93 \\
(39.74)\end{array}$ & $\begin{array}{l}100 \\
(42.02)\end{array}$ & $32(26.23)$ & $174(47.54)$ & $206(42.21)$ \\
\hline $31-40$ & $\begin{array}{l}69 \\
(29.49)\end{array}$ & $\begin{array}{l}56 \\
(23.53)\end{array}$ & $33(27.05)$ & $95(25.96)$ & $128(26.23)$ \\
\hline $41-50$ & $\begin{array}{l}45 \\
(19.23)\end{array}$ & $\begin{array}{l}37 \\
(15.55)\end{array}$ & $23(18.85)$ & 59 (16.12) & $82(16.80)$ \\
\hline $51-60$ & $\begin{array}{l}18 \\
(7.69)\end{array}$ & $\begin{array}{l}31 \\
(13.03)\end{array}$ & $22(18.03)$ & $27(7.38)$ & $49(10.04)$ \\
\hline$\geq 60$ & $9(3.85)$ & $\begin{array}{l}14 \\
(5.88)\end{array}$ & $12(9.84)$ & $11(3.01)$ & $23(4.71)$ \\
\hline \multicolumn{6}{|l|}{ Ethnicity } \\
\hline Caucasian & $\begin{array}{l}224 \\
(96.55)\end{array}$ & $\begin{array}{l}214 \\
(91.45)\end{array}$ & $114(94.21)$ & 337 (93.35) & $451(93.57)$ \\
\hline Other & $8(3.45)$ & $\begin{array}{l}20 \\
(8.55)\end{array}$ & $7(5.79)$ & $24(6.65)$ & $31(6.43)$ \\
\hline \multicolumn{6}{|l|}{ Marital Status } \\
\hline Single & $\begin{array}{l}106 \\
(46.29)\end{array}$ & $\begin{array}{l}104 \\
(44.64)\end{array}$ & $53(44.92)$ & $168(46.80)$ & $221(46.33)$ \\
\hline In a relationship & $\begin{array}{l}123 \\
(53.71)\end{array}$ & $\begin{array}{l}129 \\
(55.36)\end{array}$ & $65(55.08)$ & $191(53.20)$ & $256(53.67)$ \\
\hline \multicolumn{6}{|l|}{ Highest level of education } \\
\hline Primary or High School & $\begin{array}{l}53 \\
(23.25)\end{array}$ & $\begin{array}{l}40 \\
(17.02)\end{array}$ & 23 (19.49) & 72 (19.95) & $95(19.83)$ \\
\hline Technical school & $\begin{array}{l}62 \\
(27.19)\end{array}$ & $\begin{array}{l}41 \\
(17.45)\end{array}$ & $27(22.88)$ & $78(21.61)$ & 105 (21.92) \\
\hline College & $\begin{array}{l}68 \\
(29.82)\end{array}$ & $\begin{array}{l}77 \\
(32.77)\end{array}$ & $35(29.66)$ & $116(32.13)$ & $151(31.52)$ \\
\hline $\begin{array}{l}\text { University (e.g.:bachelor's degree, 1st cycle } \\
\text { certificate) }\end{array}$ & $\begin{array}{l}31 \\
(13.60)\end{array}$ & $\begin{array}{l}58 \\
(24.68)\end{array}$ & $22(18.64)$ & $73(20.22)$ & $95(19.83)$ \\
\hline Master's degree / Doctorate / PhD & $\begin{array}{l}14 \\
(6.14)\end{array}$ & $\begin{array}{l}19 \\
(8.09)\end{array}$ & $11(9.32)$ & $22(6.09)$ & $33(6.89)$ \\
\hline \multicolumn{6}{|l|}{ Annual income } \\
\hline$<10000$ & $9(4.00)$ & $\begin{array}{l}16 \\
(7.14)\end{array}$ & $6(5.31)$ & $20(5.68)$ & $26(5.59)$ \\
\hline
\end{tabular}




\begin{tabular}{|c|c|c|c|c|c|}
\hline $10000-24999$ & $\begin{array}{l}36 \\
(16.00)\end{array}$ & $\begin{array}{l}53 \\
(23.66)\end{array}$ & $29(25.66)$ & 70 (19.89) & 99 (21.29) \\
\hline $25000-49999$ & $\begin{array}{l}74 \\
(32.89)\end{array}$ & $\begin{array}{l}58 \\
(25.89)\end{array}$ & $25(22.12)$ & $111(31.53)$ & $136(29.25)$ \\
\hline $50000-74999$ & $\begin{array}{l}38 \\
(16.89)\end{array}$ & $\begin{array}{l}42 \\
(18.75)\end{array}$ & $23(20.35)$ & $58(16.48)$ & $81(17.42)$ \\
\hline 75000 - 99999 & $\begin{array}{l}35 \\
(15.56)\end{array}$ & $\begin{array}{l}24 \\
(10.71)\end{array}$ & $13(11.50)$ & 46 (13.07) & 59 (12.69) \\
\hline $100000-124999$ & $\begin{array}{l}17 \\
(7.56)\end{array}$ & $\begin{array}{l}12 \\
(5.36)\end{array}$ & $9(7.96)$ & $20(5.68)$ & $29(6.24)$ \\
\hline$>125000$ & $\begin{array}{l}16 \\
(7.11)\end{array}$ & $\begin{array}{l}19 \\
(8.48)\end{array}$ & $8(7.07)$ & $27(7.76)$ & $35(7.53)$ \\
\hline
\end{tabular}

*Missing answers are excluded from percentages.

$\$$ The category 'other gender' was not considered for the stratification by gender due to the low number of participants in this category

Table 2: Reasons for not seeking care in cannabis clinics 


\begin{tabular}{|c|c|c|c|c|c|c|c|c|c|c|}
\hline \multirow[t]{2}{*}{ Reason } & \multicolumn{3}{|c|}{ Gender*\# } & \multicolumn{3}{|l|}{ Age\# } & \multicolumn{3}{|c|}{ Type of cannabis use } & \multirow[t]{2}{*}{ Total } \\
\hline & $\begin{array}{l}\text { Men } \\
(n=210)\end{array}$ & $\begin{array}{l}\text { Women } \\
(n=213)\end{array}$ & $\begin{array}{l}\mathrm{p}- \\
\text { value }\end{array}$ & $\begin{array}{l}21-34 \\
(n=224)\end{array}$ & $\begin{array}{l}>34 \\
(n=214)\end{array}$ & $\begin{array}{l}\mathrm{p}- \\
\text { value }\end{array}$ & $\begin{array}{l}\text { Medical } \\
\text { only } \\
(n=113)\end{array}$ & $\begin{array}{l}\text { Medical + } \\
\text { recreational } \\
(n=326)\end{array}$ & $\begin{array}{l}\text { p- } \\
\text { value }\end{array}$ & \\
\hline $\begin{array}{l}\text { Never received } \\
\text { informations }\end{array}$ & $\begin{array}{l}102 \\
(48.57)\end{array}$ & $\begin{array}{l}122 \\
(57.28)\end{array}$ & 0.07 & $\begin{array}{l}135 \\
(60.27)\end{array}$ & $\begin{array}{l}97 \\
(45.33)\end{array}$ & 0.002 & $\begin{array}{l}60 \\
(53.10)\end{array}$ & $172(52.76)$ & 0.95 & $\begin{array}{l}232 \\
(52.85)\end{array}$ \\
\hline $\begin{array}{l}\text { Complexity of } \\
\text { the process }\end{array}$ & $\begin{array}{l}98 \\
(46.67)\end{array}$ & $\begin{array}{l}69 \\
(32.39)\end{array}$ & 0.003 & $\begin{array}{l}96 \\
(42.86)\end{array}$ & $\begin{array}{l}78 \\
(36.45)\end{array}$ & 0.17 & $\begin{array}{l}38 \\
(33.63)\end{array}$ & $137(42.02)$ & 0.13 & $\begin{array}{l}175 \\
(39.86)\end{array}$ \\
\hline $\begin{array}{l}\text { Difficulty } \\
\text { accessing } \\
\text { medical } \\
\text { cannabis } \\
\text { clinics }\end{array}$ & $\begin{array}{l}61 \\
(29.05)\end{array}$ & $\begin{array}{l}36 \\
(16.90)\end{array}$ & 0.003 & $\begin{array}{l}60 \\
(26.80)\end{array}$ & $\begin{array}{l}42 \\
(19.63)\end{array}$ & 0.07 & $\begin{array}{l}20 \\
(17.70)\end{array}$ & $82(25.15)$ & 0.11 & $\begin{array}{l}102 \\
(23.23)\end{array}$ \\
\hline $\begin{array}{l}\text { The delay } \\
\text { before } \\
\text { obtaining } \\
\text { cannabis is } \\
\text { too long }\end{array}$ & $\begin{array}{l}43 \\
(20.48)\end{array}$ & $\begin{array}{l}24 \\
(11.27)\end{array}$ & 0.009 & $\begin{array}{l}44 \\
(19.64)\end{array}$ & $\begin{array}{l}27 \\
(12.62)\end{array}$ & 0.04 & $\begin{array}{l}16 \\
(14.16)\end{array}$ & 55 (16.87) & 0.50 & $\begin{array}{l}71 \\
(16.17)\end{array}$ \\
\hline $\begin{array}{l}\text { Higher price of } \\
\text { cannabis }\end{array}$ & $\begin{array}{l}35 \\
(16.67)\end{array}$ & $\begin{array}{l}16 \\
(7.51)\end{array}$ & 0.004 & $\begin{array}{l}23 \\
(10.27)\end{array}$ & $\begin{array}{l}30 \\
(14.02)\end{array}$ & 0.23 & $\begin{array}{l}16 \\
(14.16)\end{array}$ & 37 (11.35) & 0.43 & $\begin{array}{l}53 \\
(12.07)\end{array}$ \\
\hline $\begin{array}{l}\text { Poor } \\
\text { Customer } \\
\text { service with } \\
\text { the clinics }\end{array}$ & 7 (3.33) & $5(2.35)$ & 0.54 & $8(3.57)$ & $6(2.80)$ & 0.65 & 7 (6.19) & $7(2.15)$ & 0.03 & $\begin{array}{l}14 \\
(3.19)\end{array}$ \\
\hline $\begin{array}{l}\text { Not satisfy } \\
\text { with the } \\
\text { characteristics } \\
\text { of products }\end{array}$ & $\begin{array}{l}24 \\
(11.43)\end{array}$ & $\begin{array}{l}10 \\
(4.69)\end{array}$ & 0.01 & $\begin{array}{l}17 \\
(7.59)\end{array}$ & $\begin{array}{l}20 \\
(9.35)\end{array}$ & 0.51 & $\begin{array}{l}12 \\
(10.62)\end{array}$ & $25(7.67)$ & 0.33 & $\begin{array}{l}37 \\
(8.43)\end{array}$ \\
\hline $\begin{array}{l}\text { The inability } \\
\text { to choose the } \\
\text { products } \\
\text { yourself }\end{array}$ & $\begin{array}{l}41 \\
(19.52)\end{array}$ & $\begin{array}{l}39 \\
(18.31)\end{array}$ & 0.75 & $\begin{array}{l}49 \\
(21.88)\end{array}$ & $\begin{array}{l}34 \\
(15.89)\end{array}$ & 0.07 & $\begin{array}{l}16 \\
(14.16)\end{array}$ & $67(20.55)$ & 0.13 & $\begin{array}{l}83 \\
(18.91)\end{array}$ \\
\hline $\begin{array}{l}\text { Follow-up with } \\
\text { a doctor does } \\
\text { not suit me }\end{array}$ & $\begin{array}{l}45 \\
(21.43)\end{array}$ & $\begin{array}{l}38 \\
(17.84)\end{array}$ & 0.35 & $\begin{array}{l}53 \\
(23.66)\end{array}$ & $\begin{array}{l}36 \\
(16.82)\end{array}$ & 0.07 & $\begin{array}{l}11 \\
(9.73)\end{array}$ & 78 (23.93) & 0.001 & $\begin{array}{l}89 \\
(20.27)\end{array}$ \\
\hline $\begin{array}{l}\text { Refusal of } \\
\text { physician }\end{array}$ & $\begin{array}{l}13 \\
(6.19)\end{array}$ & $\begin{array}{l}22 \\
(10.33)\end{array}$ & 0.12 & $\begin{array}{l}14 \\
(6.25)\end{array}$ & $\begin{array}{l}21 \\
(9.81)\end{array}$ & 0.16 & $\begin{array}{l}11 \\
(9.73)\end{array}$ & $24(7.36)$ & 0.42 & $\begin{array}{l}35 \\
(7.97)\end{array}$ \\
\hline $\begin{array}{l}\text { Other } \\
\text { reasons\#\# }\end{array}$ & $\begin{array}{l}21 \\
(10.00)\end{array}$ & $\begin{array}{l}21 \\
(9.86)\end{array}$ & 0.96 & $\begin{array}{l}20 \\
(8.93)\end{array}$ & $\begin{array}{l}23 \\
(10.75)\end{array}$ & 0.52 & $\begin{array}{l}15 \\
(13.27)\end{array}$ & $28(8.59)$ & 0.15 & $\begin{array}{l}43 \\
(9.79)\end{array}$ \\
\hline
\end{tabular}

* 16 participants who reported other gender were not included in the stratification

\# 50 participants whose answer was 'I don't know' were not considered in the denominator, in addition to one missing for age categorization. 
\#\# Other reasons included: Treated condition does not require a medical prescription (minor symptoms); In process to obtain medical cannabis; No prescription; Combine medical access with SQDC access; Never engaged in the process/does not feel the need for medical prescription; Stigmatisation by the healthcare system; Legal access at SQDC thus no need to go in clinics; No clinic near their location.

Table 3: Conditions and symptoms treated with cannabis according to gender and age 


\begin{tabular}{|c|c|c|c|c|c|c|c|}
\hline \multirow[t]{2}{*}{ Treated conditions } & \multicolumn{3}{|c|}{$\begin{array}{l}\text { Gender } \\
\text { (missing=3; } 16 \text { participants with 'other } \\
\text { gender' not stratified) }\end{array}$} & \multicolumn{4}{|c|}{$\begin{array}{l}\text { Age (years) } \\
\text { (missing }=4 \text { ) }\end{array}$} \\
\hline & $\begin{array}{l}\text { Men } \\
(n=233)\end{array}$ & $\begin{array}{l}\text { Women } \\
(n=237)\end{array}$ & $\begin{array}{l}\mathrm{p}- \\
\text { value }\end{array}$ & $\begin{array}{l}\leq 34 \\
(n=251)\end{array}$ & $\begin{array}{l}>34 \\
(n=234)\end{array}$ & $\begin{array}{l}\mathrm{p}- \\
\text { value }\end{array}$ & Total \\
\hline Psychological disorders & $199(85.41)$ & $\begin{array}{l}202 \\
(85.23)\end{array}$ & 0.96 & $\begin{array}{l}226 \\
(90.04)\end{array}$ & $\begin{array}{l}189 \\
(80.77)\end{array}$ & 0.0037 & $\begin{array}{l}415 \\
(85.57)\end{array}$ \\
\hline Anxiety & $155(66.52)$ & $176(74.26)$ & 0.06 & $\begin{array}{l}196 \\
(78.09)\end{array}$ & $\begin{array}{l}148 \\
(63.253)\end{array}$ & 0.0003 & $\begin{array}{l}344 \\
(70.93)\end{array}$ \\
\hline Depression & $95(40.77)$ & 78 (32.91) & 0.07 & $\begin{array}{l}113 \\
(45.02)\end{array}$ & $\begin{array}{l}71 \\
(30.34)\end{array}$ & 0.0009 & $\begin{array}{l}184 \\
(37.94)\end{array}$ \\
\hline Insomnia & $136(58.37)$ & $129(54.43)$ & 0.39 & $\begin{array}{l}148 \\
(58.96)\end{array}$ & $\begin{array}{l}126 \\
(53.85)\end{array}$ & 0.25 & $\begin{array}{l}274 \\
(56.49)\end{array}$ \\
\hline PTSD & $33(14.16)$ & $40(16.88)$ & 0.41 & $\begin{array}{l}43 \\
(17.13)\end{array}$ & $\begin{array}{l}34 \\
(14.53)\end{array}$ & 0.43 & $\begin{array}{l}77 \\
(15.88)\end{array}$ \\
\hline ADHD & $75(32.19)$ & $47(19.83)$ & 0.002 & $\begin{array}{l}68 \\
(27.09)\end{array}$ & $\begin{array}{l}56 \\
(23.93)\end{array}$ & 0.42 & $\begin{array}{l}124 \\
(25.57)\end{array}$ \\
\hline Shyness & $38(16.31)$ & $14(5.91)$ & 0.0003 & $\begin{array}{l}43 \\
(17.13)\end{array}$ & $11(4.70)$ & $\hat{0}_{0.0001}$ & $\begin{array}{l}54 \\
(11.13)\end{array}$ \\
\hline Somatic disorders & $168(72.10)$ & $184(77.64)$ & 0.17 & $\begin{array}{l}179 \\
(71.31)\end{array}$ & $\begin{array}{l}182 \\
(77.78)\end{array}$ & 0.103 & $\begin{array}{l}361 \\
(74.43)\end{array}$ \\
\hline Chronic non-cancer pain & $126(54.08)$ & $126(53.16)$ & 0.84 & $\begin{array}{l}115 \\
(46.82)\end{array}$ & $\begin{array}{l}144 \\
(61.54)\end{array}$ & 0.0005 & $\begin{array}{l}259 \\
(53.40)\end{array}$ \\
\hline Headaches/Migraines & $61(26.18)$ & $74(31.22)$ & 0.23 & $\begin{array}{l}86 \\
(34.26)\end{array}$ & $\begin{array}{l}52 \\
(22.22)\end{array}$ & 0.003 & $\begin{array}{l}138 \\
(28.45)\end{array}$ \\
\hline Bowel disease & $22(9.44)$ & $33(13.92)$ & 0.13 & $20(7.97)$ & $\begin{array}{l}35 \\
(14.96)\end{array}$ & 0.015 & $\begin{array}{l}55 \\
(11.34)\end{array}$ \\
\hline Muscle spasticity & $47(20.17)$ & $33(13.92)$ & 0.07 & $\begin{array}{l}36 \\
(14.34)\end{array}$ & $\begin{array}{l}45 \\
(19.23)\end{array}$ & 0.14 & $\begin{array}{l}81 \\
(16.70)\end{array}$ \\
\hline $\begin{array}{l}\text { Nausea/vomiting (unrelated to } \\
\text { chemotherapy) }\end{array}$ & $15(6.44)$ & $30(12.66)$ & 0.02 & $\begin{array}{l}28 \\
(11.16)\end{array}$ & $\begin{array}{l}20 \\
(8.55)\end{array}$ & 0.33 & $\begin{array}{l}48 \\
(9.90)\end{array}$ \\
\hline $\begin{array}{l}\text { Endometriosis or other } \\
\text { gynecological disorder }\end{array}$ & NA & $36(15.19)$ & - & $\begin{array}{l}27 / 125 \\
(21.60)\end{array}$ & $\begin{array}{l}8 / 112 \\
(7.14)\end{array}$ & 0.0017 & $\begin{array}{l}35 / 237 \\
(14.77)\end{array}$ \\
\hline \multicolumn{8}{|l|}{ Unclassified } \\
\hline Loss of appetite & $46(19.74)$ & $41(17.30)$ & 0.50 & $\begin{array}{l}57 \\
(22.71)\end{array}$ & $\begin{array}{l}35 \\
(14.96)\end{array}$ & 0.029 & $\begin{array}{l}92 \\
(18.97)\end{array}$ \\
\hline Sexual disorder & $14(6.01)$ & $19(8.02)$ & 0.39 & $20(7.97)$ & $\begin{array}{l}13 \\
(5.56)\end{array}$ & 0.29 & $\begin{array}{l}33 \\
(6.80)\end{array}$ \\
\hline
\end{tabular}


**Other conditions include: cancer pain $(n=3), \operatorname{cancer}(n=7)$, palliative care $(n=1)$, schizophrenia/psychosis $(n=3)$, nausea due to chemotherapy, obesity $(n=7)$, diabetes $(n=8)$, weight loss $(n=12)$, alcohol or opioid withdrawal $(n=15)$, tic disorder/Gilles de la Tourette's syndrome ( $n=3)$, tremor/Parkinson disease $(n=7)$, bladder disorder/incontinence $(n=8)$, asthma $(n=1)$, autism $(n=1)$, congestion ( $n=1)$, trigger finger $(n=1)$, gender dysphoria $(n=1)$, rash $(n=1)$, nicotine withdrawal symptom $(n=2)$; hypothyroidism $(n=1)$; snoring $(n=1)$, chronic obstructive pulmonary disease $(n=1)$, psoriasis $(n=10)$, Ehlers-Danlos Syndrome $(n=1)$, Restless legs syndrome $(n=3)$, Borderline personality disorder $(n=2)$, shingles $(n=1)$, suicidal ideation $(n=1)$, Meniere's disease $(n=)$, itchy skin $(n=1)$, mental/ocular fatigue $(n=1)$.

Table 4: Description of cannabis products used for self-treatment and mode of administration, stratified according to the type of cannabis use 
THC and CBD ratio $(n=\quad n=120$

$n=476$

476; 13 missing). p-value

$<0.0001$

\section{$n=356$}

Equal THC and CBD

16 (13.33) $73(20.51)$

89

(18.70)

$\mathrm{CBD}>\mathrm{THC}$

$33(27.50) \quad 63(17.70)$

96

(20.17)

$\mathrm{THC}>\mathrm{CBD}$

$33(27.50) \quad 136(38.20)$

169

(35.50)

Only CBD

$27(22.50) \quad 32(8.99)$

59

Only THC

$11(9.17) \quad 52(14.61)$

Only THC

$n=110$

$n=338$

CBD concentration $(n=448$; 41 missing). $p$-value <

$$
n=338
$$

0.0001

\begin{tabular}{|c|c|c|c|}
\hline$<1 \%$ & 12 (10.91) & $62(18.34)$ & $\begin{array}{l}74 \\
(16.52)\end{array}$ \\
\hline $1-10 \%$ & 30 17.86) & $138(40.83)$ & $\begin{array}{l}168 \\
(37.50)\end{array}$ \\
\hline$>10-20 \%$ & $28(25.45)$ & 100 (29.59) & $\begin{array}{l}128 \\
(28.57)\end{array}$ \\
\hline$>20 \%$ & $40(36.36)$ & $38(11.24)$ & $\begin{array}{l}78 \\
(17.41)\end{array}$ \\
\hline $\begin{array}{l}\text { THC concentration }(\mathrm{n}= \\
470 ; 19 \text { missing). P-value } \\
<0.0001\end{array}$ & $n=115$ & $n=355$ & $n=470$ \\
\hline$<1 \%$ & 33 (28.70) & $34(9.58)$ & $\begin{array}{l}67 \\
(14.26)\end{array}$ \\
\hline $1-10 \%$ & $29(25.22)$ & $72(20.28)$ & $\begin{array}{l}101 \\
(21.49)\end{array}$ \\
\hline$>10-20 \%$ & $18(15.65)$ & $133(37.46)$ & $\begin{array}{l}151 \\
(32.13)\end{array}$ \\
\hline$>20 \%$ & $35(30.43)$ & $116(32.68)$ & $\begin{array}{l}151 \\
(32.13)\end{array}$ \\
\hline
\end{tabular}

Cannabis strain $(n=426 ; \quad n=88 \quad n=338$

$p$-value $=0.8550$ 
Hybrid

20 (22.73) $\quad 84(24.85)$

104

Mixed cannabis

$18(20.45) \quad 78(23.08)$

96

(22.54)

Route of
administration $(n=489)^{\star}$

Smoking

$N=122$

$N=367$

$n=489$

Vaping

$76(62.30) \quad 321(87.47)$

397

(81.19)

17 (13.93) 70 (19.07)

87

(17.79)

Vaporizing

40 (32.79) $\quad 95$ (25.89)

135

(27.61)

Ingestion

$60(49.18) \quad 176(47.96)$

236

(48.26)

Frequency of use $(n=455 ; \quad N=114 \quad N=341$

$n=$
455 34 missing) $p$-value

$=0.0068$

$<1$ day/month

$13(11.40) \quad 13(3.81)$

26

1 day/month

$3(2.63) \quad 16(4.69)$

(5.71)

2-3 days/month

3(2.63) $16(4.69)$

19

(4.18)

18 (15.79) $36(10.56)$

54

(11.87)

1-2 days/weak

$13(11.40) \quad 33(9.68)$

46

(10.11)

3-4 days/weak

18 (15.79) 39 (11.44)

57

5-6 days/weak

7 (6.14)

38 (11.14)

45

(9.89)

Daily

$42(36.84) \quad 166(48.68)$

208

(45.71)

\section{Duration of use for} medical purpose

$N=122 \quad N=367$

$n=489$

$\mathrm{p}$-value $<0.0001$

$<1$ month

$6(4.92) \quad 6(1.63)$

12 (2.45)

1 to 6 months

$15(12.30) \quad 27(7.36)$

6-12 months

25 (20.49) 49 (13.35)

1 to 2 years

$32(26.23) \quad 59$ (16.08)

91

(18.61)

$>2$ years

$44(36.07) \quad 226(61.58)$ 
$T H C=$ tetrahydrocannabinol; $C B D=$ cannabidiol

*as routes of administration were not mutually exclusive, a global p-value was not computed. However, comparing each category value according to the type of cannabis use, only the category 'smoking' was statistically significant $(p$-value $<0.0001)$.

Table 5. Classes of other prescribed or used drugs reported by a subset of study participants $(n=247)$ 


\begin{tabular}{|c|c|c|}
\hline Likely indication & Drug class & Users $(n=247,50.51 \%)$ \\
\hline \multirow[t]{8}{*}{ Pain } & Unspecified analgesic & $36(14.57)$ \\
\hline & Opioids & $20(8.10)$ \\
\hline & NSAID & $46(18.62)$ \\
\hline & Coanalgesic & $17(6.88)$ \\
\hline & Muscle relaxant & $21(8.50)$ \\
\hline & Anti-migraine & $5(2.02)$ \\
\hline & Corticosteroid & $2(0.81)$ \\
\hline & Intestinal anti-inflammatory drug (e.g., mesalamine) & $2(0.81)$ \\
\hline \multirow[t]{6}{*}{ Mood/anxiety/sleep disorder } & Antidepressant & $84(34.01)$ \\
\hline & Serotonin-norepinephrine reuptake inhibitor & $4(1.62)$ \\
\hline & Anxiolytic & $30(12.15)$ \\
\hline & Hypnotic (z-class or benzodiazepine) & $34(13.77)$ \\
\hline & Antipsychotic & $27(10.93)$ \\
\hline & Mood stabilisers & $4(1.62)$ \\
\hline Attention deficit hyperactivity disorder & Psychostimulant & $27(10.93)$ \\
\hline \multirow[t]{5}{*}{ Cardio-vascular/ metabolic/digestive } & Antidiabetic & $2(0.81)$ \\
\hline & Antiacid & $10(4.05)$ \\
\hline & Antihypertensive & $5(2.02)$ \\
\hline & Anticoagulant & $1(0.40)$ \\
\hline & Beta-blocker & $5(2.02)$ \\
\hline \multirow[t]{3}{*}{ Asthma/ smoking/ allergies } & Antihistaminic & $2(0.81)$ \\
\hline & Nicotine replacement therapy & $1(0.40)$ \\
\hline & Inhaled corticosteroid & $2(0.81)$ \\
\hline \multirow[t]{4}{*}{ Other } & Oral contraceptive & $2(0.81)$ \\
\hline & Chemotherapy & $1(0.40)$ \\
\hline & Natural health product & $9(3.64)$ \\
\hline & Other & $16(6.48)$ \\
\hline
\end{tabular}

Co-analgesics include: gabapendinoid or tricyclic antidepressants 
Table 6. Healthcare resources and other resources utilization 


\begin{tabular}{|c|c|c|c|c|c|c|c|}
\hline & \multicolumn{3}{|l|}{ Gender } & \multicolumn{4}{|c|}{ Type of cannabis use } \\
\hline & Men & Women & p-value & $\begin{array}{l}\text { Medical } \\
\text { use } \\
\text { only } \\
(n=122)\end{array}$ & $\begin{array}{l}\text { Medical + } \\
\text { recreationnal } \\
\text { use } \\
(n=367)\end{array}$ & p-value & $\begin{array}{l}\text { Total } \\
\text { participants } \\
\left(\begin{array}{l}n=489) \mathrm{N} \\
(\%)^{*}\end{array}\right.\end{array}$ \\
\hline $\begin{array}{l}\text { Treated condition(s) were } \\
\text { diagnosed (missing=7) }\end{array}$ & $\mathrm{N}=\mathbf{2 3 2}$ & $\mathrm{N}=234$ & 0.050 & $\mathrm{~N}=120$ & $N=362$ & 0.0009 & $\mathrm{~N}=482$ \\
\hline Yes, all treated conditions & $\begin{array}{l}95 \\
(40.95)\end{array}$ & $\begin{array}{l}122 \\
(52.14)\end{array}$ & & $\begin{array}{l}73 \\
(60.83)\end{array}$ & $149(41.16)$ & & $222(46.06)$ \\
\hline Yes, but not all treated conditions & $\begin{array}{l}85 \\
(36.64)\end{array}$ & $\begin{array}{l}72 \\
(30.77)\end{array}$ & & $\begin{array}{l}29 \\
(24.17)\end{array}$ & $135(37.29)$ & & $164(34.02)$ \\
\hline No & $\begin{array}{l}52 \\
(22.41)\end{array}$ & $\begin{array}{l}40 \\
(17.09)\end{array}$ & & $\begin{array}{l}18 \\
(15.00)\end{array}$ & $78(21.55)$ & & $96(19.92)$ \\
\hline $\begin{array}{l}\text { Declaration of cannabis use to } \\
\text { healthcare professionals } \\
\text { (missing=6)\# }\end{array}$ & $N=191$ & $N=151$ & 0.1345 & $\mathrm{~N}=90$ & $N=261$ & 0.034 & $N=351$ \\
\hline Yes, always & $\begin{array}{l}111 \\
(58.12)\end{array}$ & $\begin{array}{l}72 \\
(47.68)\end{array}$ & & $\begin{array}{l}51 \\
(56.67)\end{array}$ & $135(51.72)$ & & $186(52.99)$ \\
\hline Yes, sometimes & $\begin{array}{l}56 \\
(29.32)\end{array}$ & $\begin{array}{l}52 \\
(34.44)\end{array}$ & & $\begin{array}{l}20 \\
(22.22)\end{array}$ & $92(35.25)$ & & $112(31.91)$ \\
\hline No & $\begin{array}{l}24 \\
(12.57)\end{array}$ & $\begin{array}{l}27 \\
(17.88)\end{array}$ & & $\begin{array}{l}19 \\
(21.11)\end{array}$ & $34(13.03)$ & & $53(15.10)$ \\
\hline $\begin{array}{l}\text { Resources consulted for cannabis } \\
\text { use }\end{array}$ & $\mathrm{N}=235$ & $\mathrm{~N}=238$ & & $\mathrm{~N}=122$ & $N=367$ & & $N=489$ \\
\hline Physician & $\begin{array}{l}87 \\
(37.02)\end{array}$ & $\begin{array}{l}51 \\
(21.43)\end{array}$ & 0.0002 & $\begin{array}{l}34 \\
(27.87)\end{array}$ & $109(29.70)$ & 0.700 & $143(29.24)$ \\
\hline pharmacist & $\begin{array}{l}19 \\
(8.09)\end{array}$ & $\begin{array}{l}17 \\
(7.14)\end{array}$ & 0.70 & $9(7.38)$ & $27(7.36)$ & 0.99 & $36(7.36)$ \\
\hline $\begin{array}{l}\text { Legal recreational cannabis store } \\
\text { (i.e., SQDC) agent }\end{array}$ & $\begin{array}{l}73 \\
(31.06)\end{array}$ & $\begin{array}{l}102 \\
(42.86)\end{array}$ & 0.0079 & $\begin{array}{l}53 \\
(43.44)\end{array}$ & $127(34.60)$ & 0.079 & $180(36.81)$ \\
\hline Illegal seller & $\begin{array}{l}25 \\
(10.64)\end{array}$ & $\begin{array}{l}18 \\
(7.56)\end{array}$ & 0.24 & $6(4.92)$ & 39 (10.63) & 0.059 & $45(9.20)$ \\
\hline $\begin{array}{l}\text { Agent from a cannabis production } \\
\text { company }\end{array}$ & $\begin{array}{l}18 \\
(7.66)\end{array}$ & $\begin{array}{l}13 \\
(5.46)\end{array}$ & 0.33 & $\begin{array}{l}10 \\
(8.20)\end{array}$ & $22(5.99)$ & 0.39 & $32(6.54)$ \\
\hline Psychologist or psychotherapist & $\begin{array}{l}26 \\
(11.06)\end{array}$ & $\begin{array}{l}15 \\
(6.30)\end{array}$ & 0.066 & $9(7.38)$ & $32(8.72)$ & 0.64 & $41(8.38)$ \\
\hline Naturopath or herborist & $9(3.83)$ & $6(2.52)$ & 0.42 & $4(3.28)$ & $12(3.27)$ & 0.99 & $16(3.27)$ \\
\hline Other resources* & $\begin{array}{l}31( \\
13.19)\end{array}$ & $\begin{array}{l}20 \\
(8.40)\end{array}$ & 0.093 & $\begin{array}{l}19 \\
(15.57)\end{array}$ & $36(9.81)$ & 0.081 & $55(11.25)$ \\
\hline Never consulted & $\begin{array}{l}88 \\
(37.45)\end{array}$ & $\begin{array}{l}98 \\
(41.18)\end{array}$ & 0.406 & $\begin{array}{l}39 \\
(31.97)\end{array}$ & $152(41.42)$ & 0.064 & $191(39.06)$ \\
\hline $\begin{array}{l}\text { Information sought by consulting a } \\
\text { resource }(n=298 \text { as } 191 \text { never } \\
\text { consulted a resource) }\end{array}$ & $N=147$ & $N=140$ & & $N=83$ & $N=215$ & & $N=298$ \\
\hline
\end{tabular}




\begin{tabular}{|c|c|c|c|c|c|c|c|}
\hline $\begin{array}{l}\text { Methods of cannabis } \\
\text { consumption }\end{array}$ & $\begin{array}{l}28( \\
19.05)\end{array}$ & $\begin{array}{l}45( \\
32.14)\end{array}$ & 0.011 & $\begin{array}{l}28 \\
(33.73)\end{array}$ & $46(21.40)$ & 0.027 & $74(24.83)$ \\
\hline $\begin{array}{l}\text { Available varieties and } \\
\text { concentrations/potencies of } \\
\text { cannabis products }\end{array}$ & $\begin{array}{l}69( \\
46.94)\end{array}$ & $\begin{array}{l}85( \\
60.71)\end{array}$ & 0.027 & $\begin{array}{l}47 \\
(56.63)\end{array}$ & 115( 53.49) & 0.626 & $\begin{array}{l}162( \\
54.36)\end{array}$ \\
\hline Efficacy of cannabis & $\begin{array}{l}78( \\
53.06)\end{array}$ & $\begin{array}{l}86( \\
61.43)\end{array}$ & 0.152 & $\begin{array}{l}52 \\
(62.65)\end{array}$ & $118(54.88)$ & 0.225 & $\begin{array}{l}170( \\
57.05)\end{array}$ \\
\hline $\begin{array}{l}\text { Safety of cannabis/adverse } \\
\text { effects }\end{array}$ & $\begin{array}{l}31( \\
21.09)\end{array}$ & $\begin{array}{l}24( \\
17.14)\end{array}$ & 0.396 & $\begin{array}{l}17 \\
(20.48)\end{array}$ & 41 ( 19.07) & 0.783 & $58(19.46)$ \\
\hline $\begin{array}{l}\text { Safety to combine cannabis with } \\
\text { other medication }\end{array}$ & $\begin{array}{l}35( \\
23.81)\end{array}$ & $\begin{array}{l}37( \\
26.43)\end{array}$ & 0.609 & $\begin{array}{l}25( \\
30.12)\end{array}$ & $51(23.72)$ & 0.256 & 76 ( 25.50) \\
\hline $\begin{array}{l}\text { Subjective effect of cannabis } \\
\text { ('high') }\end{array}$ & $\begin{array}{l}33( \\
22.45)\end{array}$ & $\begin{array}{l}23( \\
16.43)\end{array}$ & 0.198 & $4(4.82)$ & $56(26.05)$ & $<0.0001$ & $60(20.13)$ \\
\hline Other \& & $\begin{array}{l}12( \\
8.16)\end{array}$ & $\begin{array}{l}5( \\
3.57)\end{array}$ & 0.099 & $\begin{array}{l}4 \\
(4.82)\end{array}$ & $16(7.44)$ & 0.417 & $20(6.71)$ \\
\hline \multicolumn{8}{|l|}{$\begin{array}{l}\text { Willingness to have access to } \\
\text { healthcare professional regarding } \\
\text { cannabis use ( } n=343 ; \\
\text { missing=14)\# }\end{array}$} \\
\hline Yes & $\begin{array}{l}146 \\
(79.78)\end{array}$ & $\begin{array}{l}122 \\
(80.79)\end{array}$ & 0.82 & $\begin{array}{l}72 \\
(80.00)\end{array}$ & $204(80.63)$ & 0.90 & $276(80.47)$ \\
\hline
\end{tabular}

*Other resources included: friends/relative/other patients; internet (Health Canada documentations, scientific articles, online forums), nurses, social worker, Physiotherapist and nutritionist;

\& Other included: substitution of cannabis with benzodiazepines and antidepressants, information on the medical access process, if their health condition could be treated with cannabis, risk of dependence with cannabis, information on the reimbursement by insurance, information on the endocannabinoid system, what to do in case of intoxication.

\#these variables were completed by a subset of the participants $(n=357)$ as these questions were added to the questionnaire after the launch of the survey. 